\title{
Water relations in cut calla lily flowers maintained under different postharvest solutions
}

\author{
Thais Silva Sales $^{1}\left(\mathbb{D}\right.$, Patrícia Duarte de Oliveira Paiva $^{2}$ (), Guilherme Mariano Manfredini ${ }^{2}$ (), \\ Ângela Maria Pereira do Nascimento ${ }^{2 *}$ (1), Michele Valquíria dos Reis ${ }^{2}$ (]) \\ ${ }^{1}$ Universidade Federal dos Vales do Jequitinhonha e Mucuri, Departamento de Agricultura, Diamantina-MG, Brazil. \\ ${ }^{2}$ Universidade Federal de Lavras, Departamento de Agricultura, Lavras-MG, Brazil.
}

\begin{abstract}
The use of chemicals in storage solutions has proved beneficial for the postharvest conservation of cut flowers. However, the effect of these solutions on the water relations of some species is still unknown. Therefore, the objective of the present investigation was to evaluate the water relations in calla lily flowers harvested at different stages and maintained under postharvest solutions with different chemicals. The flower stems were harvested in two stages of spathe opening: the early stage (cartridge) and the $1 / 3$ flower opening stage. The flower stems were dipped in solutions with water (control), $100 \mathrm{mg} \mathrm{L}^{-1}$ sodium hypochlorite $(\mathrm{NaClO})$, $100 \mathrm{mg} \mathrm{L}^{-1}$ aluminum sulfate $\left[\mathrm{Al}_{2}\left(\mathrm{SO}_{4}\right)_{3}\right], 200 \mathrm{mg} \mathrm{L}^{-1} 8$-hydroxyquinoline (8-HQ) and $10 \mathrm{mg} \mathrm{L}^{-1}$ silver nitrate $\left(\mathrm{AgNO}_{3}\right)$. Over 9 days, the floral stems were kept in a room at $21 \pm 2{ }^{\circ} \mathrm{C}$ and $75 \% \pm 5 \%$ relative humidity and evaluated for changes in the $\mathrm{pH}$ of the solution and the water absorption, transpiration and commercial quality of the cut flowers. The addition of conservation substances to the storage solution induced spathe opening at both harvest stages and promoted water absorption by the stems, thus increasing the efficiency of flower hydration. The water balance maintenance was best for stems stored in water and storage solutions with $\mathrm{Al}_{2}\left(\mathrm{SO}_{4}\right)_{3}$.
\end{abstract}

Keywords: Zantedeschia aethiopica, chemicals, floriculture, vase life.

\section{Resumo}

Relações hídricas em flores de copo-de-leite mantidas em diferentes soluções pós-colheita

O uso de produtos químicos em soluções de armazenamento tem demonstrado efeitos benéficos para a conservação pós-colheita de flores. No entanto, o efeito dessas soluções nas relações hídricas de algumas espécies ainda é desconhecido. Portanto, objetivouse avaliar as relações hídricas em flores de copo-de-leite colhidas em diferentes estágios e mantidas em soluções com diferentes produtos. As hastes das flores foram colhidas em dois estágios de abertura da espata: o estágio inicial (cartucho) e 1/3 de abertura. Estes foram acondicionados em soluções com água (controle), $100 \mathrm{mg} \mathrm{L}^{-1}$ de hipoclorito de sódio ( $\mathrm{NaClO}$ ), $100 \mathrm{mg} \mathrm{L}^{-1}$ de sulfato de alumínio $\left[\mathrm{Al}_{2}\left(\mathrm{SO}_{4}\right)^{3}\right.$ ], $200 \mathrm{mg} \mathrm{L}^{-1}$ 8-hidroxiquinolina (8-HQ) e $10 \mathrm{mg}$ de nitrato de prata $\mathrm{L}^{-1}$ (AgNO3). Ao longo de 9 dias, as hastes florais foram mantidas em uma sala com temperatura de $21 \pm 2{ }^{\circ} \mathrm{C}$ e umidade relativa de $75 \% \pm 5 \%$ e avaliadas quanto ao pH da solução, absorção de água, transpiração e qualidade comercial. A adição de substâncias de conservação à solução de armazenamento induziu a abertura da espata nos dois estágios de colheita e contribuiu para a absorção de água pelas hastes, melhorando a hidratação das flores. A melhor manutenção do balanço hídrico foi observada para hastes armazenadas em água e soluções de armazenamento com $\mathrm{Al}_{2}\left(\mathrm{SO}_{4}\right)^{3}$.

Palavras-chave: Zantedeschia aethiopica, produtos químicos, floricultura, vida em vaso.

\section{Introduction}

Calla lilies are usually harvested when they show extended spathes (Almeida et al., 2009); however, different harvest stages have been recently accepted for use in decoration. Harvesting at earlier stages (closed or partial opening) can provide inflorescences with better quality and longevity (Carneiro et al., 2014; Sales et al., 2015; Mattos et al., 2017, Sanches et al., 2017, Sales et al., 2018, Nascimento et al., 2019). However, limited information

*Corresponding author: angela_mpn2@yahoo.com.br 
is available on the influence of chemicals in the storage solution on the longevity and water relations of early harvested floral stems.

Water relations are important factors that restrict the vase life of most flowers after harvest (Van Doorn, 2012). Water stress is caused mainly by the drastic decrease in water absorption in the stem, which can be caused by microbial growth, air bubble formation, lithophytes and suberin and lignin deposition in the xylem vessels. After harvest, some flower species have a limited vase life due to drought stress since the transpiration rates may be higher than the water absorption (Costa et al., 2015).

The addition of certain chemicals to storage solutions has had beneficial effects on the postharvest conservation of cut flowers. These products, such as sodium hypochlorite $(\mathrm{NaClO})$, may prevent bactericidal contamination. The mechanism of action of chlorine is non-specific and involves the oxidation of the cellular components of microbial agents, including the proteins of cellular and protoplasmic membranes (Dychdala, 1983). The application of sodium hypochlorite improved the vase life of several cut flowers (Jowkar, 2015; Bastos et al., 2016).

8-Hydroxyquinoline (8-HQ) or its sulfate (8-HQS) and citrate (8-HQC) esters present germicide properties and are widely used in storage solutions because they inhibit microorganism growth (Jowkar et al., 2017) and vascular occlusion and promote solution absorption by the plant. Solutions containing 8-HQS showed better water consumption, prevented microorganism growth in conductive vessels and weight loss, and extended the vase life of Alstroemeria, Antirrhinum majus, and hydrangea flowers (Ali and Hassan, 2014; Kabari and Solimandarabi, 2019; Kazaz et al., 2019). The use of 8-HQC and sucrose also improved the storage life of Gladiolus grandiflorus (Belwal Sheeba et al., 2019).
Silver nitrate $\left(\mathrm{AgNO}_{3}\right)$ is a highly effective biocide that inhibits microbial growth and prevents vascular occlusion, thereby limiting water absorption (Malakar et al., 2019). Additionally, Oncidium inflorescences treated with $\mathrm{AgNO}_{3}$ in combination with HQC and sucrose showed high longevity (Mattiuz et al., 2015). Silver nitrate may also have inhibitory effects on ethylene action (Taiz et al., 2017) and can increase the diameter of rose stems after cutting (Shailendra et al., 2016).

The addition of antimicrobial agents ( $\mathrm{HQS}$ and $\mathrm{AgNO}_{3}$ ), ethylene inhibitor $\left(\mathrm{AgNO}_{3}\right)$ and sucrose to conservation solutions results in better flower quality and longevity. These products increase the carbohydrate contents and water uptake, delay senescence, maintain flower turgidity, reduce bacterial proliferation and prevent xylem blockages in gladiolus (Mishra and Khanal, 2019).

Aluminum sulphate $\left(\mathrm{Al}_{2}\left(\mathrm{SO}_{4}\right)_{3}\right)$ has been recommended for maintaining the vase life of gladioluses and roses (Seyf et al., 2012; Gupta et al., 2020) since it acidifies the storage solution, limits bacterial growth and favors water absorption (Ichimura et al., 2006).

Considering that the effects of certain chemical compounds in conservation solutions on the water relations of postharvest calla lilies in the early stages are unknown, the present investigation was performed.

\section{Materials and Methods}

\section{Plant materials}

Calla lily (Zantedeschia aethiopica) flower stems from flowering plants were collected early in the morning (7-8 a.m.) from a commercial producer. The opening stages of the spathe at harvest were categorized as the early stage (cartridge) and 1/3 opening stage of flowers (Figure 1) according to Sales et al. (2018), who recommended that these stages would promote higher commercial durability.

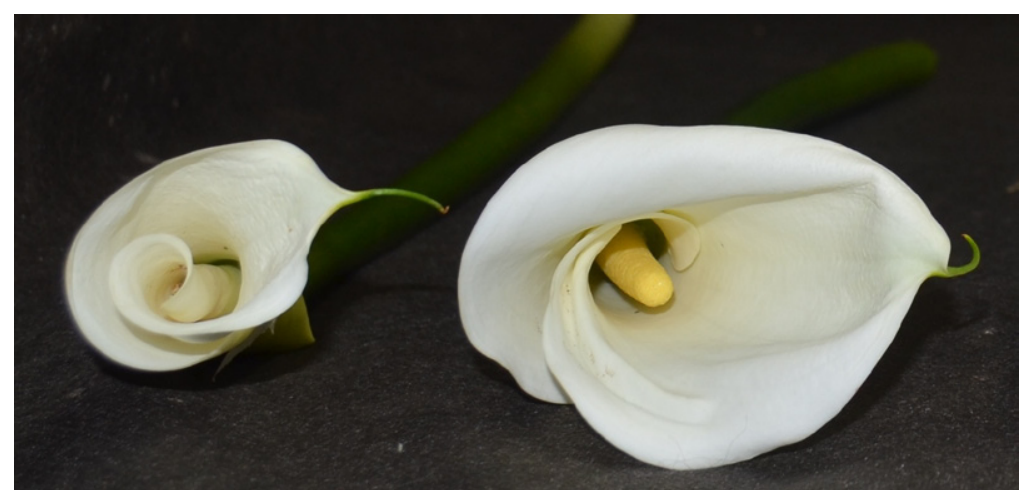

Figure 1. Harvest stages of calla lily flower stems: early stage spathe (cartridge) (left) and 1/3 open (right) (Sales et al., 2018). 
The lilies were then transported dry for one hour to the laboratory, where they were immersed in water and kept at $21{ }^{\circ} \mathrm{C}$. Once selected and standardized at $50 \mathrm{~cm}$, the stems were weighed to determine the fresh weight and subjected to the treatment conditions.

\section{Experimental protocol}

The experiment consisted of 10 treatments resulting from a factorial design with 2 harvest stages and 5 storage solutions: water (control), $100 \mathrm{mg} \mathrm{L}^{-1}$ sodium hypochlorite ( $\mathrm{NaClO}), 100 \mathrm{mg} \mathrm{L}^{-1}$ aluminum sulfate $\left[\mathrm{Al}_{2}\left(\mathrm{SO}_{4}\right)_{3}\right], 200 \mathrm{mg}$ $\mathrm{L}^{-1} 8$-hydroxyquinoline (8-HQ), and $10 \mathrm{mg} \mathrm{L}^{-1}$ silver nitrate $\left(\mathrm{AgNO}_{3}\right)$. Each stem was placed in a plastic pot containing $0.5 \mathrm{~L}$ of storage solution, which was supplemented daily. The pots were sealed with a plastic bag around the stem to prevent water evaporation.

The flower stems in the vase treatment solution were placed in a room at $21 \pm 2{ }^{\circ} \mathrm{C}$ and $75 \% \pm 5 \%$ relative humidity. Assessments of the water $\mathrm{pH}$, presence of pollen, commercial quality, width and length of the spathe, fresh weight of the stem, water absorption and transpiration were performed daily over 9 days.

\section{Quality analysis}

The analysis of the commercial quality of the flower stems was based on the pattern determined by Almeida et al. (2008):

- Class A1: turgid inflorescences, with an inclined spathe tip and the absence of roughness or necrosis;

- Class A2: turgid inflorescences, with the spathe tip slightly rolled down and the absence of roughness or necrosis;

- Class B: turgid inflorescences, with the spathe tip slightly rolled down, the presence of roughness, and the absence of necrosis;

- Class C: wilted inflorescences, with the spathe tip rolled down and the presence of necrosis.

The assessments of flower stem quality showed that the sum of the days in which the stems remained in classes A1, A2 and B represented the pot life of these inflorescences. Stems classified as A1 had the best quality, while those classified as $\mathrm{C}$ were considered waste.

\section{Physiological analysis}

The absorption rate was estimated by determining the volume of consumed water in $\mathrm{mL} \mathrm{d}^{-1}$ as evaluated per stem; whereas the transpiration rate was estimated in $\mathrm{g} \mathrm{d}^{-1}$ as evaluated per stem according to Sales et al. (2015): $\mathrm{T}=\mathrm{V}_{\mathrm{c}}$ - $\left(\mathrm{MH}_{\mathrm{f}}-\mathrm{MH}_{\mathrm{i}}\right)$, where T represents the transpiration rate $(\mathrm{g}$ $\left.\mathrm{d}^{-1}\right) ; \mathrm{V}_{\mathrm{c}}$ represents the consumed solution volume $(\mathrm{g}) ; \mathrm{MH}_{\mathrm{i}}$ represents the early stem weight $(\mathrm{g})$; and $\mathrm{MH}_{\mathrm{f}}$ represents the late stem weight $(\mathrm{g})$.
Changes in fresh weight were determined by the daily weighing of flower stems, and the value was determined according to Sales et al. (2015): VMF $=\left(M_{\mathrm{f}} \times 100\right) / \mathrm{M}_{\mathrm{i}}$; where VMF represents the variation in fresh weight $(\%)$; $M_{i}$ represents the stem fresh weight on the first day of evaluation $(\mathrm{g})$; and $\mathrm{M}_{\mathrm{f}}$ represents the stem fresh weight on the day of evaluation $(\mathrm{g})$.

The water balance was calculated by the difference between the absorption rate and the transpiration rate, and it was expressed in $\mathrm{mL} \mathrm{d}^{-1}$ as evaluated per stem according to He et al. (2006).

\section{Experimental design and statistical analysis}

The experimental design consisted of 10 treatments with 2 harvest stages and 5 storage solutions resulting from a factorial design. Three replicates and two stems per plot were used. The model used was a split plot based on time, in which the opening stages and storage solutions represented the plot and the days of evaluation represented the subplot. Qualitative data obtained in the experiment were pooled and submitted to Tukey's test at the 5\% probability level and analyzed with the aid of the R software (R Development Core Team, 2018).

\section{Results and Discussion}

The storage solutions for the maintenance of calla lily stems after harvest showed different $\mathrm{pH}$ levels as a result of the different chemicals used. The storage solution containing only water (control) and the solution with silver nitrate $\left(\mathrm{AgNO}_{3}\right)$ had average $\mathrm{pH}$ values of 7.2 ; the solution with sodium hypochlorite $(\mathrm{NaClO})$ had the highest average $\mathrm{pH}$ of 8.7 ; the solution with 8-hydroxyquinoline (8-HQ) had a $\mathrm{pH}$ of 7.1; and the solution with aluminum sulfate $\left[\mathrm{Al}_{2}\left(\mathrm{SO}_{4}\right)_{3}\right]$ had a lower average $\mathrm{pH}$ of 4.4 . The use of substances that maintain low water $\mathrm{pH}$ levels is recommended to slow senescence because lower $\mathrm{pH}$ limits microbial growth and promotes greater longevity (Ahmad et al., 2013; Shanan, 2017); however, calla was tolerant to high water $\mathrm{pH}$ (Ahmad et al., 2013).

\section{Quality analysis}

Differences were not observed in the postharvest quality between inflorescences stored in different solutions and the harvest stage in terms of the permanence of the stems in classes $\mathrm{A} 1$ or $\mathrm{A} 1+\mathrm{A} 2$ or $\mathrm{A} 1+\mathrm{A} 2+\mathrm{B}$, which was because of the harvest stages (Table 1). Flower stems harvested in early stages remained longer in class A1 (5.4 days) and had greater longevity (7.7 days for the commercial classes $\mathrm{A} 1+\mathrm{A} 2+\mathrm{B})$. For stems harvested at $1 / 3$ open, the average for the best quality class (A1) was 4.3 days and the longevity was 7.4 days for the classes $\mathrm{A} 1+\mathrm{A} 2+\mathrm{B}$. 
Table 1. Number of days in which the calla lily flower stems stored at room temperature remained in qualitative classes $\mathrm{A} 1, \mathrm{~A} 1+\mathrm{A} 2$, and $\mathrm{A} 1+\mathrm{A} 2+\mathrm{B}$ as a function of the harvest stage.

\begin{tabular}{|c|c|c|c|}
\hline \multicolumn{2}{|c|}{ Days* $^{*}$} \\
\hline Harvest stage & Class A1 & Class A1+A2 & Class A1+A2+B \\
\hline Early stage & $5.4 \mathrm{a}$ & $6.1 \mathrm{a}$ & $7.7 \mathrm{a}$ \\
\hline $1 / 3$ open & $4.3 \mathrm{~b}$ & $6.0 \mathrm{a}$ & $7.4 \mathrm{~b}$ \\
\hline
\end{tabular}

*Means followed by the same letter in columns do not differ by the Tukey's test at the 5\% probability level.

Flower stems harvested in the early stage persisted for approximately 1 day longer in class A1 when compared with the flower stems harvested at $1 / 3$ open. In classes $\mathrm{A} 1+\mathrm{A} 2$, differences were not observed between the harvest stages, and although differences were observed in both stages (early and $1 / 3$ open stages) in classes $A 1+A 2+B$, the flower stems persisted for approximately 7 days. Thus, as already observed by Sales et al. (2015), floral stems harvested at the early stages of spathe opening have greater durability.

Moreover, the stems harvested at $1 / 3$ open persisted an average of 4.6 days longer without pollen presence on the spadix, while for stems harvested at the early stage, the average was 3.5 days. The formation of pollen grains may be related to weather conditions, particularly the environmental temperature when flowers are forming
(Almeida et al., 2008). Flower stems with the presence of pollen in the spadix have reduced commercial quality and show considerable acceleration in the signs of senescence in the spathe, such as wilting and abscission (Paiva and Almeida, 2012).

Flower opening and spathe width and length were influenced by the harvest stage and storage solution. Stems harvested at $1 / 3$ open showed greater spathe expansion relative to those in the early stage, and the maximum widths were 11.3 and $9.9 \mathrm{~cm}$, respectively (Figure 2).

Regarding the length of the spathe, flower stems harvested at $1 / 3$ open also showed greater expansion and reached a maximum length of $14.6 \mathrm{~cm}$, and flower stems harvested at the early stage showed a maximum value of $12.30 \mathrm{~cm}$ (Figure 3).

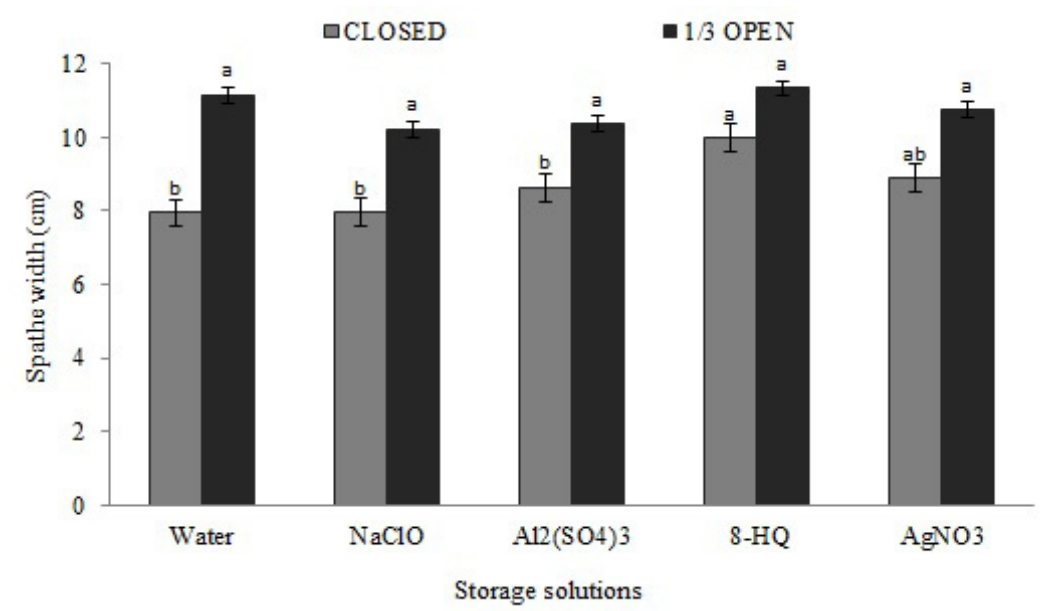

Figure 2. Spathe width of calla lily flower stems as a function of the harvest stage and storage solutions. Means followed by the same letter for the harvest stage do not differ by Tukey's test at the 5\% probability level. 


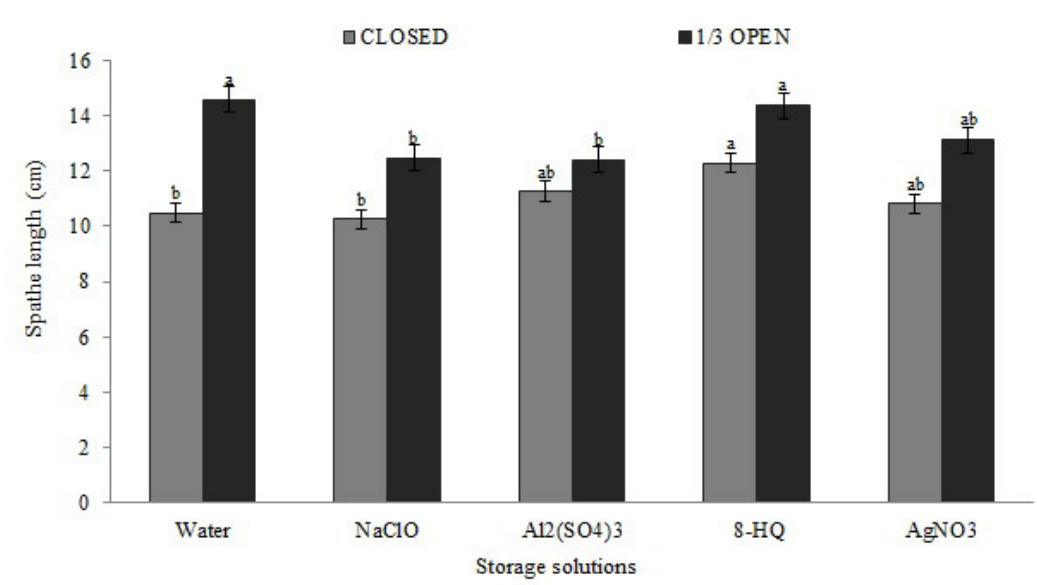

Figure 3. Spathe length of calla lily flower stems as a function of the harvest stage and storage solution. Means followed by the same letter for the harvest stage do not differ by Tukey's test at $5 \%$ probability.

Stems harvested at the early stage showed stronger effects of the storage solutions, with the use of 8-HQ and $\mathrm{AgNO}_{3}$ inducing greater openness as demonstrated by the greater width. In the stems harvested at 1/3 open, differences were not observed between the storage solutions and the control.

Similarly, the stems harvested at the early stage had a greater increase in spathe length when kept in a solution with $8-\mathrm{HQ}$, followed by the solutions with $\mathrm{Al}_{2}\left(\mathrm{SO}_{4}\right)_{3}$ and $\mathrm{AgNO}_{3}$. When harvested at $1 / 3$ open, the stems kept in water and in solution with 8-HQ showed greater length.

These observations indicate that the addition of chemicals to the storage solution allows for flower stem harvest at earlier stages, which leads to more efficient spathe opening. In lisianthus, the use of 8-HQC in the vase solution also helps increase the floral opening and pot life (Hutchinson, 2013). Considering the harvest of stems at $1 / 3$ open, namely, stems that are mature or at a slightly more advanced maturation stage, the use of products in the solution is not required because of the limited effectiveness in terms of floral growth.

\section{Physiological analysis}

The fresh weight variation in the harvested calla lily flower stems was influenced by the spathe opening stage and storage solution (Figure 4).

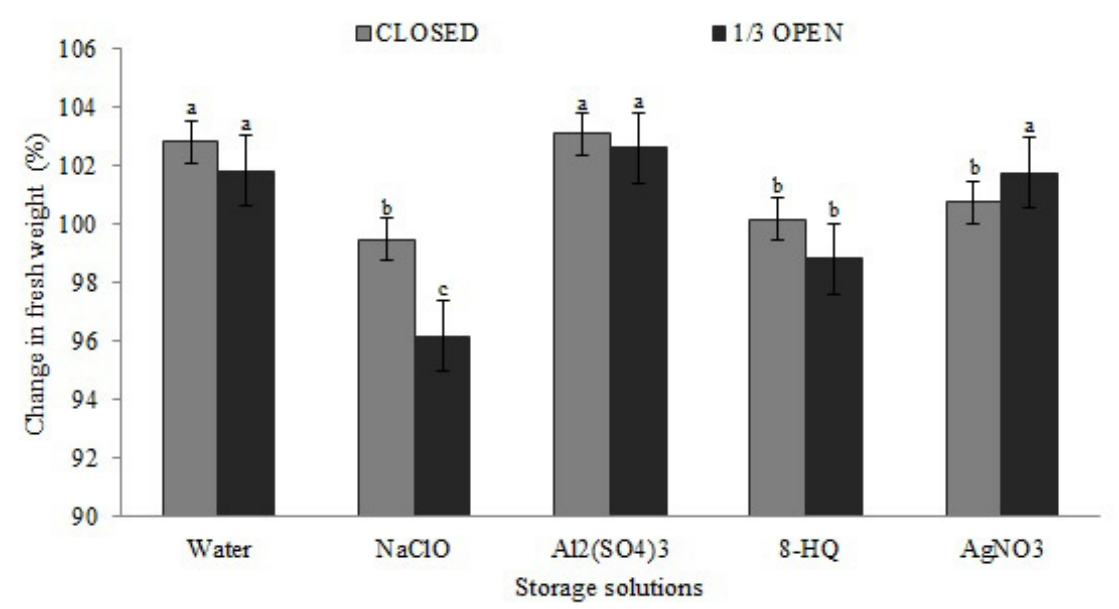

Figure 4. Percentage change in the fresh weight of calla lily flower stems as a function of the harvest stage and storage solution. Means followed by the same letter for the harvest stage do not differ by

Tukey's test at the 5\% probability level. 
Stems harvested at the early and 1/3 open stages showed differences when kept in $\mathrm{NaClO}$ and 8-HQ, with the lowest fresh weight variation obtained in the early stage. Stems harvested at the early stage and stored in the solution with $\mathrm{Al}_{2}\left(\mathrm{SO}_{4}\right)_{3}$ and in water had higher fresh weight (103.1 and $102.8 \%$, respectively) (Figure 4). Although storage solutions containing $\mathrm{AgNO}_{3}, 8-\mathrm{HQ}$ and $\mathrm{NaClO}$ provided similar results, a fresh weight loss $(0.5 \%)$ was observed for stems in the $\mathrm{NaClO}$ solution, which was probably due to the high $\mathrm{pH}$.

When the stems were $1 / 3$ open, those stored in the solutions with $\mathrm{Al}_{2}\left(\mathrm{SO}_{4}\right)_{3}$ and $\mathrm{AgNO}_{3}$ and in water showed an increase in fresh weight. Although no differences were observed between these solutions, the largest increase $(102.6 \%)$ occurred in stems stored in the solution with $\mathrm{Al}_{2}\left(\mathrm{SO}_{4}\right)_{3}$. However, for stems kept in the storage solution with $8-\mathrm{HQ}$, a $1.2 \%$ loss of fresh weight was observed, and for those kept in the solution with $\mathrm{NaClO}$, the losses were more pronounced at $3.8 \%$.

Stems kept in the solution containing $\mathrm{Al}_{2}\left(\mathrm{SO}_{4}\right)_{3}$ and in only water showed a greater increase in fresh weight than the other treatments, suggesting that vascular occlusion by microorganisms did not occur since water absorption was not affected. Phytosanitary substrates in the preservative solutions are used to keep the water of the solution clean and promote the sanitation and durability of the vase life of flowers (Dias, 2016). However, the decrease in $\mathrm{pH}$ by the use of $\mathrm{Al}_{2}\left(\mathrm{SO}_{4}\right)_{3}$ in the storage solutions may have favored absorption by the stems. The aluminum sulphate solution (150 and $300 \mathrm{mg} \mathrm{L}^{-1}$ ) also promoted an increase in water absorption, fresh weight, and diameter of the flower buds of the rose cultivar 'Boeing' (Seyf et al., 2012). The postharvest performance of cut scapes of Amaryllis belladonna can be improved to a great extent by the combined application of antimicrobial compounds and sugar sources (Gul et al., 2020).

An analysis of the absorption rate of calla lily stems showed that alterations were associated with the harvest stage, storage solution and days after harvest (Figure $5)$. The absorption rates of stems harvested at the early and $1 / 3$ open stages (Figure $5 \mathrm{~A}$ and $5 \mathrm{~B}$ ) were higher in the first days after harvest and decreased with the senescence process until the 8 th day after harvest, which corresponds to the end of pot life. Moreover, the $1 / 3$ open stage had higher absorption when compared to the early stage.
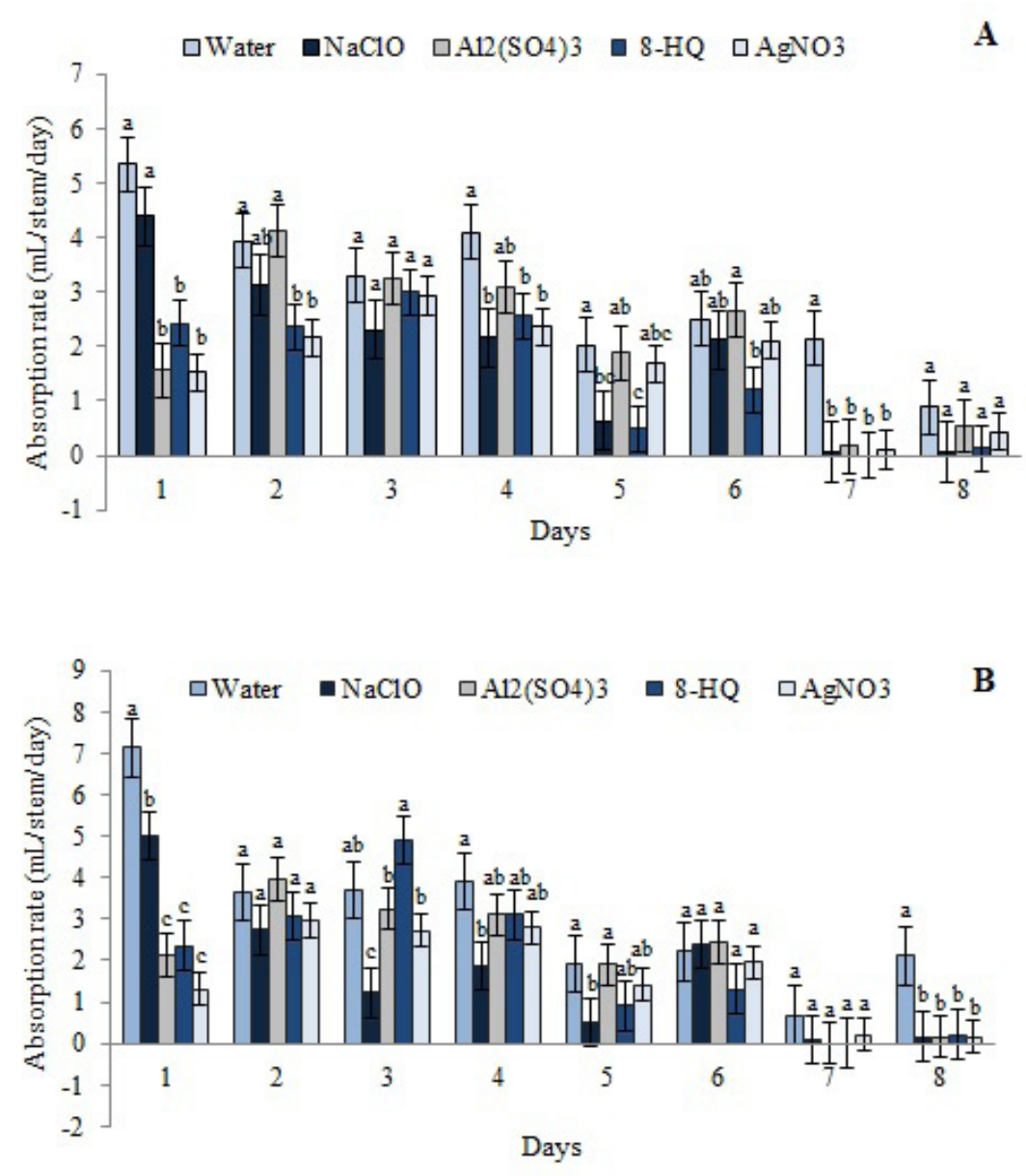

Figure 5. Absorption rate of calla lily flower stems as a function of the harvest stage (early stage-A and 1/3 open-B), storage solution and days after harvest. Means followed by the same letter for each day do not differ by Tukey's test at the 5\% probability level. 
In both harvest stages, the highest absorption rate was observed in the stems kept in water and the storage solution with aluminum sulfate (Figure 5). The increased absorption rate with the addition of $\mathrm{Al}_{2}\left(\mathrm{SO}_{4}\right)_{3}$ can be attributed to the germicidal effect of this compound, which reduces microbial proliferation and thereby reduces vascular occlusion. Furthermore, the reduction in the $\mathrm{pH}$ of the solution directly influences the absorption rate (Hutchinson, 2013). The acidification by aluminum sulfate extended the vase life of Gardenia jasminoides flowers due to the increase water uptake (Çelikel et al., 2020).

The solution containing $\mathrm{NaClO}$ showed a high absorption rate in the first day, which was followed by a sharp decline in absorption. Such low absorption values may be associated with tissue disruption at the base of the flower stems that prevented the stems from absorbing the solution. The concentration of sodium hypochlorite was probably high, or the period in which the inflorescences remained in solution may have been extended too long. Moreover, the solution containing $2 \%$ sodium hypochlorite decreased the longevity of calla lily inflorescences (Almeida et al., 2007).

The transpiration rate showed the same pattern as the absorption rate and was influenced by the harvest stage, storage solution, and days after harvest (Figure $6)$. The transpiration rate in both stages oscillated over the time (Figure 6A and 6B). These results demonstrate a direct relationship between absorption (Figure 5) and transpiration rates since more hydrated flower stems had higher water loss.
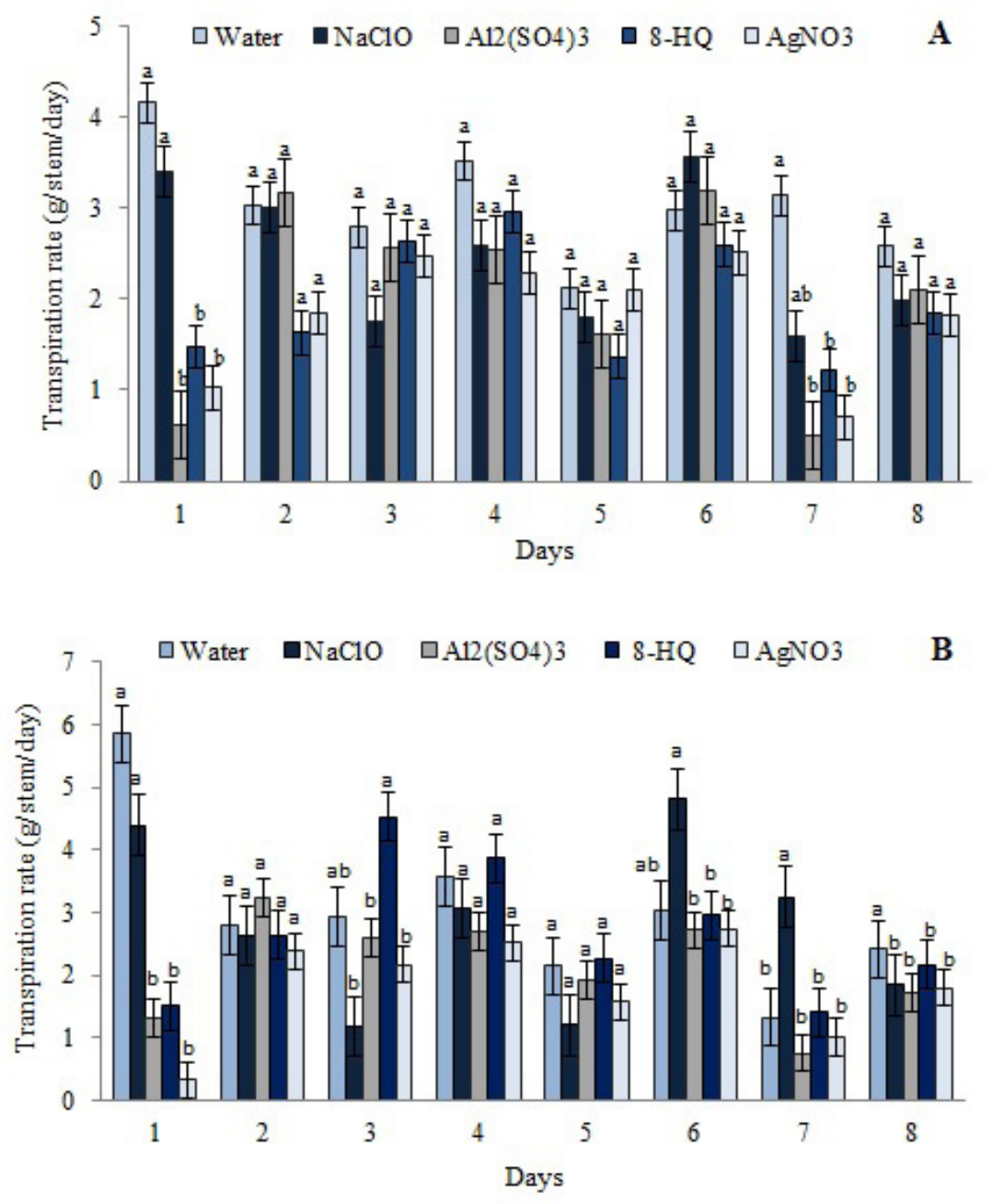

Figure 6. Transpiration rate of calla lily flower stems as a function of the harvest stage (early stage-A and 1/3 open-B), storage solution and days after harvest. Means followed by the same letter for each day do not differ by Tukey's test at the 5\% probability level.

In general, stems harvested at the early stage presented lower transpiration rates compared with those harvested at $1 / 3$ open, which was probably due to lower spathe opening. In both harvest stages, transpiration was reduced in the stems kept in solutions with $\mathrm{Al}_{2}\left(\mathrm{SO}_{4}\right)_{3}$ and $\mathrm{AgNO}_{3}$.

Initially, all stems showed positive water conditions; that is, the absorption rate was higher than the transpiration rate (Figure 7). In the early stage, the water balance for the stems that remained in storage solutions with $\mathrm{NaClO}, 8-\mathrm{HQ}$ and $\mathrm{AgNO}_{3}$ became negative starting on the 4th day after harvest. Moreover, stems kept in water and $\mathrm{Al}_{2}\left(\mathrm{SO}_{4}\right)_{3}$ persisted one day longer with a positive water balance and had a higher water balance (Figure 7A). 

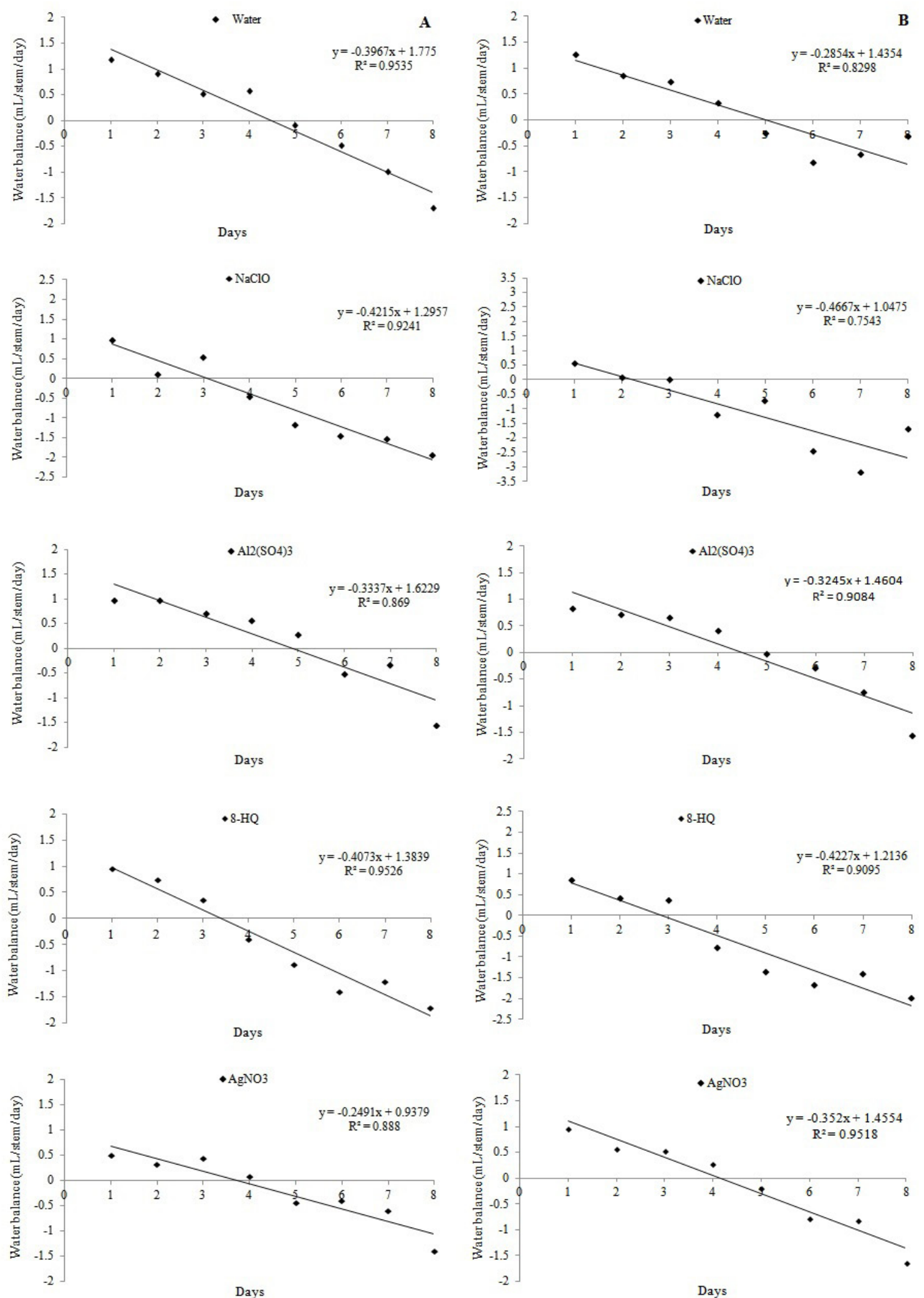

Figure 7. Regression analysis of the water balance of calla lily flower stems as a function of the harvest stage (early stage-A and $1 / 3$ open-B), storage solution and days after harvest. 
The durability of cut flowers is influenced by the absorption, retention capacity, transport and loss of water in the tissues (Gupta and Dubey, 2018), and these parameters are directly related to the durability. The turgescence of flower stems is caused by the balance between absorption and transpiration rates (Elhindi, 2012), and it is related to the visual quality of the flowers (Nascimento et al., 2019). At the $1 / 3$ open harvest stage, the stems kept in $\mathrm{NaClO}$ and $8-\mathrm{HQ}$ had a negative water balance from the 3 rd day after harvest. The stems kept in water or a solution containing $\mathrm{Al}_{2}\left(\mathrm{SO}_{4}\right)_{3}$ or $\mathrm{AgNO}_{3}$ had a negative water balance starting on the 5th day, and an increase on fresh weight occurred (Figure 4).

\section{Conclusions}

The addition of certain chemicals to the storage solution was effective at opening the spathe. The addition of 8-HQ increased flower opening in the stems harvested at the early stage. Flower stems harvested at the early and $1 / 3$ open stages presented efficient water absorption by the stems and positive flower hydration and showed better water balance maintenance when stored in solutions with $\mathrm{Al}_{2}\left(\mathrm{SO}_{4}\right)_{3}$.

\section{Author Contribution}

TSS: experiment performing, collected the data and analysis, text writing. PDOP: project idea, formulation of the aims, research planning, data analysis, text writing and critical review. GMM: experiment performing, collected the data. AMPN: experiment performing, data analysis and statistics, text writing. MVR: experiment performing, data analysis, text writing and critical review.

\section{Acknowledgements}

This research was supported by the CAPES (Coordenação de Aperfeiçoamento de Pessoal de Nível Superior), CNPq (Conselho Nacional de Desenvolvimento Científico e Tecnológico) and FAPEMIG (Fundação de apoio à Pesquisa do estado de Minas Gerais.

\section{References}

AHMAD, I.; DOLE, J.M.; CARLSON, A.S.; BLAZICH, F.A. Water quality effects on postharvest performance of cut calla, hydrangea, and snapdragon. Scientia Horticulturae, v.153, p.26-33, 2013.

ALI, E.; HASSAN, F. Postharvest quality of Strelitzia reginae Ait. cut flowers in relation to 8-hydroxyquinoline sulphate and gibberellic acid treatments. Scientia Agricola, v.1, n.3, p. 97-102, 2014.

ALMEIDA, E.F.A.; PAIVA, P.D.O.; LIMA, L.C.O.; RESENDE, M.L.; TAVARES, T.S.; CARNEIRO, D.N.M.; FONSECA, J.; PAIVA, R. Soluções de condicionamento para conservação pós-colheita de inflorescências de copode-leite armazenadas em câmara fria. Ciência Rural, v.37, n.5, p.1442-1445, 2007.
ALMEIDA, E.F.A.; PAIVA, P.D.O.; LIMA, L.C.O.; RESENDE M.L.; FONSECA, J.; TAVARES, T.S. Pós-colheita de copo-de-leite: efeito de diferentes conservantes comerciais e armazenamento a frio. Ciência e Agrotecnologia, v.32, n.4., p.1189-1194, 2008.

ALMEIDA, E.F.A.; PAIVA, P.D.O.; LIMA, L.C.O.; RIBEIRO, M.N.O.; MORAES, D.N.; RESENDE M.L.; TAVARES, T.S.; PAIVA, R. Senescência de inflorescências de copo-de-leite: influência de diferentes armazenamentos e procedimentos pós-colheita. Revista Brasileira de Horticultura Ornamental, v.15, n.1, p.71-76, 2009. https://doi.org/10.14295/rbho.v15i1.437

BASTOS, F.E.A.; STANGER, M.C.; ALLEBRANDT, R.; STEFFENS, C.A.; KRETZSCHMAR, A.A.; RUFATO, C.L. Conservação de rosas 'carola' utilizando substâncias com potencial biocida. Ornamental Horticulture, v.22, n.1, p.107-113, 2016. https://doi.org/10.14295/ oh.v22i1.806

BELWAL SHEEBA, B.B.D.; SRIVASTAVA RANJAN, S.N.C.; SATISH, C. Standardization of floral preservatives for storage and vase life enhancement of Gladiolus grandiflorus var. nova Lux. Progressive Horticulture, v.51, n.2, p.196-200, 2019.

CARNEIRO, D.N.N.; PAIVA, P.D.O.; CARNEIRO, L.F.; RODRIGUES, R.R.; LIMA, L.C.O.; DIAS, G.N.G.; PEDROSO, R.G.A.V. Estádios de abertura floral e condicionamento em inflorescências de bastão-doimperador. Ornamental Horticulture, v.20, n.2, p.163170, 2014. https://doi.org/10.14295/rbho.v20i2.578.

ÇELIKEL, F.G.; REID, M.S.; JIANG, C.Z. Postharvest physiology of cut Gardenia jasminoides flowers. Scientia Horticulturae, v.265, n.5, 2020. https://doi.org/10.1016/j. scienta.2019.108983

COSTA, L.C.; COSTA, R.R.; RIBEIRO, W.S.; CARNEIRO, G.G.; BARBOSA, J.A.; FINGER, F.L. Postharvest longevity of Heliconia wagneriana, Acta Horticulturae, v.1060, n.1, p.193-199, 2015. https://doi. org/10.17660/ActaHortic.2015.1060.28

DIAS, G.M. Quality management of tropical plants, Ornamental Horticulture, v.22, n.3, p.256-258, 2016. https://doi.org/10.14295/oh.v22i3.961

DYCHDALA, G.R. Chlorine and chlorine compounds. In: BLOCK, S.S. (Ed.). Disinfection, sterilization, and preservation. 3ed. Philadelphia: Lea e Febiger, 1983. p.157-182.

ELHINDI, M.K. Evaluation of several holding solutions for prolonging vase-life and keeping quality of cut sweet pea flowers (Lathyrus odoratus L.). Saudi Journal of Biological Science, v.19, n.2, p.195-202, 2012. 
GUL, F.; TAHIR, I.; SHAHRI, W. Flower senescence and some postharvest considerations of Amaryllis belladonna cut scapes. Plant Physiology Reports, v.25, n.2, p.315324, 2020. https://doi.org/10.1007/s40502-020-00506-8

GUPTA, J.; DUBEY, R.K. Factors affecting post-harvest life of flower crops. International Journal of Current Microbiology and Applied Sciences, v.7, n.1, p.548-557, 2018. https://doi.org/10.20546/ijcmas.2018.701.065

GUPTA, S.; KUMAR, A.; PATHAK, S.; MAURYA, N. Biocides effect on different cultivars of gladiolus (Gladiolus grandiflorus L.) to assess the vase life. The Pharma Innovation Journal, v.9, n. 5, p.274-277, 2020. 10.13140/RG.2.2.31988.99207

HE, S.; JOYCE, D.C.; IRVING, D.E.; FARAGHER; J.D. Stem end blockage in cut Grevillea 'Crimson Yullo' inflorescences. Postharvest Biology \& Technology, v.41, n.1, p.78-84, 2006. https://doi.org/10.1016/j. postharvbio.2006.03.002

HUTCHINSON, M.J. Effects of chemical preservatives and water quality on postharvest keeping quality of cut Lisianthus (Eustoma grandiflorum L). Botswana Journal Agriculture Applied Sciences, v.9, n.1, p. 8-18, 2013.

ICHIMURA, K.; TAGUCHI, M.; NORIKOSHI, R. Extension of the vase life in cut roses by treatment with glucose, isothiazolinonic germicide, citric acid and aluminum sulphate solution. Japan Agricultural Research Quarterly, v.40, n.3, p.263-269, 2006. https:// doi.org/10.6090/jarq.40.263

JOWKAR, M.M. Effects of chlorination and acidification on postharvest physiological properties of Alstroemeria, cv. 'Vanilla' and on microbial contamination of vase solution. Horticulture Environmental and Biotechnology, v.56, n.4, p.478-486, 2015. https://doi.org/10.1007/s13580-0150022-4

JOWKAR, M.M.; HASSANZADEH, N.; KAFI, M.; KHALIGHI, A. Comprehensive microbial study on biocide application as vase solution preservatives for cut 'Cherry Brandy' rose flower. International Journal of Horticultural Science and Technology, v.4, n.1, p. 89103, 2017. 10.22059/ijhst.2018.213028.146

KABARI, S.F.M.; SOLIMANDARABI, M.J. Improving Alstroemeria vase life by plant extracts and 8-Hydroxyquinoline sulfate. Journal of Ornamental Plants, v.9, n.1, p.1-11, 2019.
KAZAZ, S.; DOGAN, E.; KILIC, T.; SAHIN, E.G.E.; SEYHAN, S. Influence of holding solutions on vase life of cut hydrangea flowers (Hydrangea macrophylla thunb.). Fresenius Environmental Bulletin, v.28, n.4, p.35543559, 2019.

MALAKAR, M.; ACHARYYA, P.; BISWAS, S. Effect of silver nitrate and sucrose on the vase life of Gerbera (Gerbera jamesonii H. Bolus) cut flowers. Journal of Crop and Weed, v.15, n.2, p.46-51, 2019.

MATTIUZ, C.F.M.; MATTIUZ, B.; RODRIGUES, T.J.D.; MARQUES, K.M.; MARTIN, R.N. Effectiveness of postharvest solutions for the conservation of cut Oncidium varicosum (Orchidaceae) inflorescences. Ciência e Agrotecnologia, v.39, n.4, p.315-322, 2015. https://doi. org/10.1590/S1413-70542015000400001

MATTOS, D.G.; PAIVA, P.D.O.; NERY, F.C.; VALE, R.P.; SARTO, M.T.; LUZ, I.C.A. Water relations in post-harvested torch ginger affected by harvest point and carnauba wax. Postharvest Biology and Technology, v.127, p.35-43, 2017. https://doi.org/10.1016/j.postharvbio.2016.12.007

MISHRA, P.; KHANAL, A. Vase life analysis of gladiolus using different vase solutions. Journal of Bioscience and Agriculture Research, v.21, n.1, p.1749-1754, 2019.

NASCIMENTO, A.M.P.; PAIVA, P.D.O.; MANFREDINI, G.M.; SALES, T.S. Harvest stages and pulsing in ornamental sunflower 'Sunbright Supreme'. Ornamental Horticulture, v.25, n.2, p.149-157, 2019. https://doi. org/10.14295/oh.v25i2.1991

PAIVA, P.D.O.; ALMEIDA, E.F.A. Produção de Flores de Corte. vol.1. Lavras: Editora UFLA, 2013. 678p.

R Development Core Team (2018) R: a language and environment for statistical computing. Vienna: $R$ Foundation for Statistical Computing.

SALES, T.S.; PAIVA, P.D.O.; MANFREDINI, G.M.; NASCIMENTO, A.M.P.; CASTRO, M.L.R. Water relations in calla lily flower stems harvested at different opening stages. Ornamental Horticulture, v.21, n.3, p.368-375, 2015.https://doi.org/10.14295/oh.v21i3.736

SALES, T.S.; PAIVA, P.D.O.; SIQUEIRA, H.H.; MANFREDINI, G.M.; LIMA, L.C.O. Preservative solutions on quality and biochemical aspects of calla lily flowers. Ciência e Agrotecnologia, v.42, n.2, p.176-185, 2018. https://doi.org/10.1590/1413-70542018422020717 
SANCHES, A.G.; COSTA, J.M.; SILVA, M.B.; MOREIRA, E.G.S.; COSME, S.S. Relação entre o estádio de abertura floral e pulsing na vida útil do copo de leite. Journal of Neotropical Agriculture, v.4, n.3, p.9-14, 2017. https:// doi.org/10.32404/rean.v4i3.1400

SEYF, M.; KHALIGHI, A.; MOSTOF, Y.; NADERI, R. Study on the effect of aluminum sulfate treatment on postharvest life of the cut rose 'Boeing' (Rosa hybrida cv. Boeing). Journal of Horticulture, Forestry and Biotechnology, v.16, n.3, p.128-132, 2012.

SHAILENDRA, S.; AMIT, K.; ASHISH, K. Effect of different chemicals and different doses on vase life of cut rose CV "first Red" and Grand Gala. Annals of Horticulture, v.9, n.2, p.216-219, 2016. 10.5958/09764623.2016.00043.8
SHANAN, N.T. Optimum $\mathrm{pH}$ value for improving postharvest characteristics and extending vase life of Rosa hybrida cv. Tereasa cut flowers. Asian Journal of Advances in Agricultural Research, v.1, p.1-11, 2017. 10.9734/AJAAR/2017/34655

TAIZ, L.; ZEIGER, E.; MOLLER, I.; MURPHY, A. Fisiologia e desenvolvimento vegetal. 6.ed. Porto Alegre: Artmed, 2017. 888 p.

VAN DOORN, W.G. Water relations of cut flowers: an update. JANICK, J. (Ed.). Horticultural Reviews. Hoboken: John Wiley \& Sons, 2012. p.55-106. 